\title{
Conception of Society and Its Characteristics from an Islamic Perspective
}

\author{
HAYATULLAH LALUDDIN 1
}

\begin{abstract}
Islam presents a unique and comprehensive view of the concept of society. For, it perceives it as an association formed in accordance with the Divine revelation contained in Quran and the Sunnah of the prophet, synthesising material, and the spiritual aspects of human life. It views society as an organic whole, where all aspects of life are considered as a component part of the body hence, negating sectarianism and racism. Therefore, this paper attempts to illuminate the concept of society from Islamic perspective and analyse the nature and characteristics of social order in Islam. It also throw some light on the social principles devised by Islam for the formation of an integrated social system, and the measures for nourishment and nurturing of the internal and external aspects of human nature. Using an analytical approach the paper concludes that Islam presents a dynamic conception of the society embodying universal characteristics hence, capable of transforming all humanity to a single brotherhood.
\end{abstract}

Keywords: brotherhood, conception of society, human nature, Islamic society

Islam perceives society as an association, which is formed in accordance to the divine law with the purpose of harmonious and peaceful coexistence. The Divine revelation as contained in the al-Quran and the Sunnah of the Prophet Muhammad (s.a.w.) constitutes the foundation of social order in Islamic society. Therefore, there is no room for sectarianism or racism in Islamic conception of society. It is a universal social system based on the principle of tawhid (Oneness of God), which is the cornerstone of the world unity. It is through submission to the law of God that Islamic society attains universal characteristic and transform all humankind to a single brotherhood (Muhammad 1977). Therefore, this paper analyses society from Islamic perspective and present some of its distinctive characteristics. It also presents an image of Islamic society as a model society, which caters for both internal and external aspects of human nature.

\section{Concept of Society in Islam}

The conception of society in Islam is much more comprehensive, for it synthesises material and spiritual aspects of human life and views society as an organic whole, where all aspects of life considered as parts of a body, and where the affliction of individual part will equally affect the whole. In contrary to the Islamic conception of society, where the divine law takes precedence over society, sociology perceives society to take precedence over the law. As such, the law is a social product and formulated to serve the interest of each member of the society. Thus, the man made law, being the product of human desire and fancy, cannot provide a permanent basis for regulating human conduct. It is susceptible to changes that occur in the society. On the other

\footnotetext{
1 Hayatullah Laluddin, Ph.D., Assistant Professor, Dept. of Economics, Kulliyyah of Economics and Management Sciences, International Islamic University, 53100 KUALA LUMPUR, Malaysia, email: hayatul@iiu.edu.my.
} 
hand, divine law is immutable it furnishes permanent basis for regulating human conduct and behaviour. It never allows society to change or stray from the right path. Thus, the Islamic conception of society originated in the immutable divine law that aims at promotion of righteous life and the prevention of evil. Comte, the founding father of sociology perceived society as the outgrowth of family, the basic social unit, from which arise tribes and nations. On the contrary, Islam perceives every individual as a social unit, for he is the centre of gravity and is the launching instrument that can put Islam or any other system into full action on a full scale (Abdalati 1978). The role of individual, in such capacity, is because it is by means of his qualities and action that social relations emerge and constitute the life of the society.

Therefore, in recognition of this fact, Islam provides all opportunities for the development of individual personality to enable him contribute to the welfare of the society. However, it also imposes certain limit on individual to prevent him from coming into conflict with the rest of the society. This is done through character building, which basic elements consist of the knowledge of one's duties toward God and society and the practical training received through the pillar or cardinal principles of Islam. The latter demands from him righteous deed and piety in the form of salat (daily prayer), zakat (poor due), sawm (fasting in the month of Ramadan) and hajj (pilgrimage to Mecca once in a lifetime, for those with means). The performance of these obligations has a tremendous effect on individual character, for, it purifies his soul and prepares him for self-sacrifices, the very ethos of Islamic society. Thus, individuals with such character find pleasure in doing good to others and prefer others above themselves. A society based on such spirit is not prone to any permanent state of conflict and therefore can be likened to an organism of harmonious development (Abdalati 1978). As stated in the Quran (59:9):

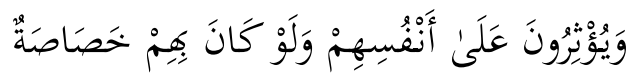

Nevertheless, give preference to other over them even though poverty was their own lot.

\section{Tawhid (Oneness of God)}

The recital of the 'kalimah of shahadah' (testifying or to bear witness) which embodies acknowledgment and the acceptance of the unique reality of God and the prophecy of Muhammad (s.a.w.) is the fundamental principle upon which all Islamic activities depend. Hence, belief in the Oneness of God is the First principle of Islam and everything Islamic. Its implication is that God is only One, and the only Creator and that everything else is separate and different from Him. He is the source of all goodness, justice and truth. Everything that happened in the past or is in the process of happening or going to happen is all within His knowledge and with His command. His will is the law of nature and the law of morality. All creatures worship and praise Him in their own way (Abu Sulayman 1989). Belief in the Oneness of God implies the unity of moral law, for believer should practice what he believes otherwise, mere acceptance of faith without living up to it is meaningless. Therefore, coordination between faith and actions is of crucial importance. This is clear from the Quranic verse (61:2) where contradiction between faith and action is condemned:

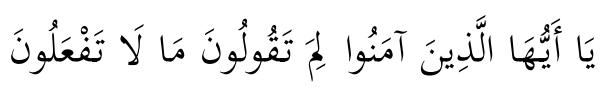

0 you who believe! Why profess you that which you do not practice. 
Therefore, the effectiveness of faith requires action, which in its turn is good only when it is in accordance with the belief. It is for this reason that the moral law of Islam requires unity between belief and action, as well as thought and deeds. After all moral values are meant to be realized in action and not merely to be accepted in theory, for their actualisation in real life is possible only when people live up to them (al-Buti 1987). The significance of practice as regard to belief is also clear from the saying of the prophet (s.a.w.), in which he told a group of Muslims who were studying together in the Mosque of Madina: "Acquire of knowledge as much as you can afford. But always remember that God reward comes only with action" (al-Shatibi $1087 \mathrm{AH}$ ).

Obviously, a society with individuals of such moral character would automatically be good. It is for this reason that, Islam focuses more on individual character and trains him to be a good member of the society. On the contrary, sociology trivializes individual and speak of society and its scientific study, which is theoretical and fruitless. Islam takes a realistic view of the society, for it acts upon the principle 'Take care of the individual, who form the society, and the society will take care of itself' (Muhammad 1977). The effect of belief in the unity of God and His attribute is quite clear, for it cultivates in believer a sense of awareness of his accountability before God in the day of Hereafter, and a sense of responsibility towards society. This awareness prevents believer from committing sin and indulgence in lying, deceiving, and selfishness, which have negative effect on the society. This is due to his conviction that selfishness deprives his brethren-in-faith of sharing in the bounties of God. Also believe in the unity of God is the most effective means of achieving social solidarity and brotherhood. This is clear from the history of humankind, for they were split into various sects and groups due to the difference in their object of believe and religion.

\section{Unity and Brotherhood}

The social system of Islam is based upon sound and just principles, which are designed to secure happiness and prosperity for both individual and society. It does not tolerate class warfare, social caste, or domination of individual over society or vice versa. It advocates the unity of humankind and its equality before God. This unity of humankind is perceived to be due to the common parentage of Adam and Eve and due to the same Creator - creation relationship that Divine unity has with all humans, different only in degree of righteousness (Abu Sulayman 1989). Therefore, the fact that humanity is descended from one universal family, entitles everyone to enjoy the common benefit and to share the common responsibility.

Humankind's realization of the unity of his origin and nature purifies his mind from racial prejudice or social injustice, and facilitate the unity of social behaviour among the people in the same manner as they are united in nature by the bond of common parentage. This unity of humanity by nature and origin is stressed in many Quranic verses and the tradition of the prophet (s.a.w.), to eliminate racial pride and claims of national or ethnic superiority, and prepare the ground for genuine brotherhood. The Quran states the unity of origin of human being as follow $(4: 1)$ :

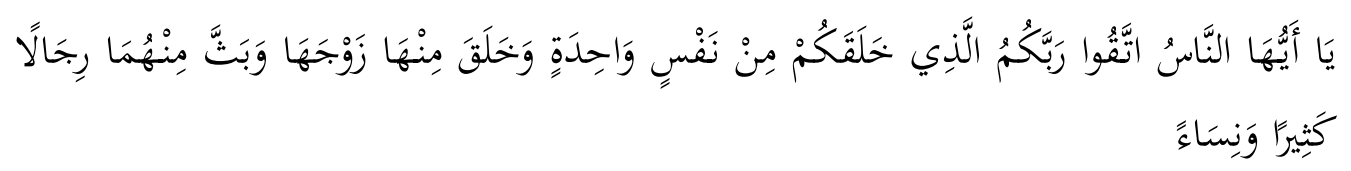

O Mankind! Reverence your Guardian-Lord, who created you from a single person, created of like nature his mate, and from them spread countless men and women.

Thus, the conception of the unity of humankind by origin and its consequent behavioural unity are the hallmarks of Islamic social system. Islam conceives human unity not only in terms of his origin and nature but also in terms of ultimate goal, which is to worship God and serve his 
cause, the cause of truth and justice, of love and mercy, of brotherhood and morality. Therefore, this unity of origin and the ultimate goal constitute formidable basis of the relation between individual and society. It bring about social solidarity between individual and society which manifest itself in terms of mutual responsibility; individual being responsible for the welfare of the society and to God (Abdalati 1978). As a result, of this realization the individual members of society develop a sound social mindedness and a genuine feeling of inescapable responsibility. In the same manner, society is responsible to God for the welfare of the individual. Thus, individual is expected to contribute to society when he has the capacity to do so. In return for this, the society is responsible for his security and welfare especially in case of his disability. Accordingly, the realization of the unity of origin, in the framework of social relation, leads to harmonious correspondence between duties, rights, and mutual responsibility. Individual's rights are preserved and respected as long as they are not in conflict with the societal responsibility. Meanwhile, no individual or class of individual is allowed to exploit the society and corrupt the state. Thus, it became clear that in Islamic social system the relation between individual and the society is bounded by harmony, peace, and mutual security.

In addition to the unity of humanity in origin and ultimate goal and mutual responsibility, cooperation in goodness and piety is another important feature of Islamic social system. Besides, full recognition of individual's sacred rights to life, property and honour, it requires him to play active role in the domain of social morals and ethics. He cannot remain indifferent in this regard and is duty bound to play active role in establishing a sound social morality by promoting good and preventing the evil by all means available to him. The lack of sense of responsibility in the social structure is an indication of low morale, disordered conscience and undernourished faith and selfishness on the part of its individual members (Abdalati 1978). Consequently, Islamic social system provides a very lofty, sound and comprehensive way of life based on sincere love for one's fellow human being, mercy for the young, respect for the elders, comfort and consolation for the distressed, visiting sick, relieving the grieved, genuine feeling of brotherhood and social solidarity, respect for the right of other people to life, property and honour, mutual responsibility between individual and society. These patterns of the Islamic social order are admirably stated in the last sermon that the prophet Muhammad (s.a.w.) delivered during his last pilgrimage to Mecca.

The sermon of the prophet underlines the sanctity of life, property, and honour as the fundamental right of human being and therefore, should be taken into account in the framework of social relation. The viability of social system depends on its ability to preserve and promote these fundamental rights. It also demonstrates the equality of humankind and fellowship of the believers and their mutual responsibility and concern. Therefore, believe in the Oneness of God play the most effective role in society of such characteristics. It bring about unity among the believers through purifying their soul from evil tendency and selfishness, and nurture in them altruism, the highest moral quality. They no longer live for themselves but for all their brothers in God's creation and avoid all that qualities which are in contradiction to God's attributes of mercy and justice.

The conception of society from Islamic perspective is free from any discriminatory patterns based on caste and creed, for it stress on the equality of humankind with the freedom of thought and action. This is due to the common parentage of the humankind, for, all humankind descended from one single pair, Adam and Eve. Thus, there is no ground for racial discrimination in Islamic conception of the society. All tribes, races, and nations are conceived as only labels of knowing differing characteristics. They are all one before God and the most honoured before Him is the one who is the most righteous. As stated in the Quran (49:13):

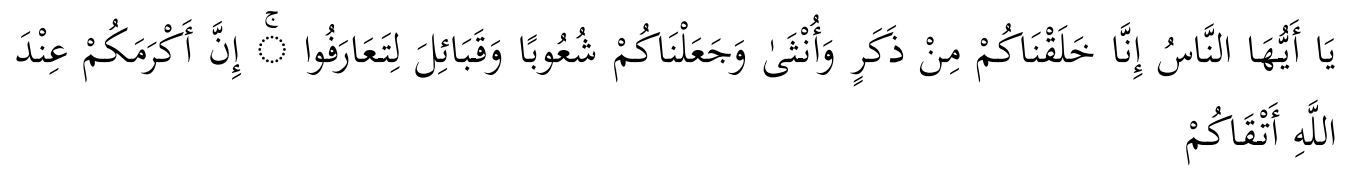


0 mankind! We created you from a single pair of a male and a female and made you into nations and tribes that ye may know each other, Verily the most honoured of you in the sight of God is he who is the most righteous of you.

From this verse, it is clear that race, colour or clan do not constitute the criterion based on which individual merit of superiority can be judged. The only criterion for one's merit is his/her righteous deed that he/she carries out in society. Thus, righteousness is the only standard of greatness which believers are required to cooperate on and not to cooperate on its opposite which is sin and rancour, as is stated in the Quran (5:2):

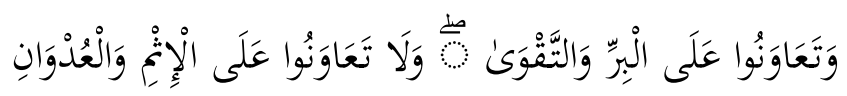

Cooperate and help one another in righteousness and piety, and not in sin and rancour.

\section{Balance and Truth}

Islam presents the best type of society, which is balanced and is free from extremes. It considers it a virtue to avoid the extreme on either side and take the middle course of affairs. The Quran states $(2: 143)$ (3:110) this position of Islam:

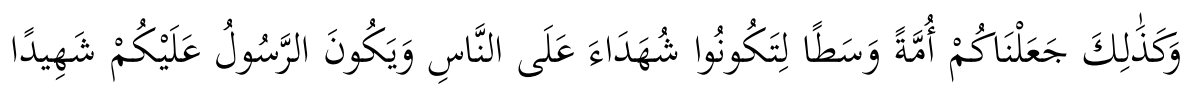

We have moulded you into a society justly balanced that ye may be a pattern unto others, even as the prophet (s.a.w.) has been a pattern unto you.

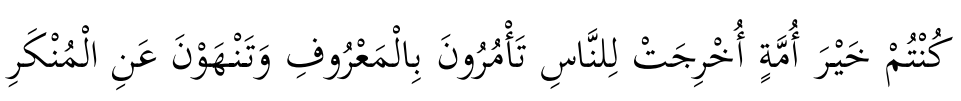

You are the best of people evolved for mankind enjoining what is right, forbidding what is wrong.

Therefore, Islamic society is a social system of universal character, which guides scattered and strayed humanity to the right path, through the belief in the Oneness of God. Although in the past, philosopher and thinkers made many attempts and many messengers were sent to attain the unity of humankind and to spread the eternal light of God's grace. However, their efforts and message lacked the character of universality, for they were meant for certain people and certain period of time. However, Islam as a justly balanced and truth message of God enjoys the character of universality. For, it is addressed to the whole humanity regardless of time and space factors, and stresses on the brotherhood of humankind and their love for each other.

It is true that other divine religions acted in the same manner, however, the merit of Islam lies in the fact that it does not entertain any conception showing the superiority of race or a group of people over others. For example, Judaism has the conception of specially chosen people and Christianity the claim of recovering the last sheep of Israel. Furthermore, Islam does not entertain the notion of the kingdom of God in the heaven and the kingdom of Caesar on earth, as held by Christianity. This meritorious status of Islam is rightly pointed by Kerr: "In professing to provide man with a political and legal system as well as spiritual faith, Islam denies at the outset, the conception familiar to Christianity of separation between temporal and spiritual matters" (Kerr 1966). Hitti make similar observation to the same effect by saying that: "Moses was a prophet, so were Abraham, Noah, Christ and others, each with a dispensation appropriate 
for a certain time. But Muhammad's dispensation sums up well as it supersedes all earlier ones. It is final after it there is none" (Hitti 1961). From these statements, it become clear that Islam is a comprehensive and universal massage without any discriminatory patterns, and views all humanity as one brotherhood on the basis of the Oneness of God.

The universality of Islam and its all-embracing nature is due to its embodiment of all aspects of human life, body and soul, individual and social, worldly and the hereafter, God and His relation to man and the universe. In such capacity, it was delivered by Muhammad s.a.w.. the last messenger as guidance to the whole humanity. The unity of God constituting the cornerstone of Islam was to express itself in the unity of man. In fact, Islam is the religion preached by all earlier prophets to particular group or society in certain time and place. But its perfection as a world order that cast across physical barrier and unite humanity under the truth of God was accomplished by the prophet Muhammad (s.a.w.) the last prophet of God.

Consequently, the concept of prophethood and revelation play a dominant role in the conception of society in Islam, for it is seen as the source of guidance to humanity through which virtue, peace and blessing in this world and the Hereafter is made possible. The prophethood is not the psycho-mental and physiological qualities of the prophet, which could be due to overexcited nerves or stirred imagination. Rather it is a source of model human physical, moral, and intellectual perfection (el-Mesawi 1998). It is a real phenomenon through which linkage between the heaven and the earth and between God and man is established. The underlying purpose of the prophethood and revelation is to import knowledge of the right and wrong to humanity and guide them to the straight path of God, manifested in individual sound social behaviour in the society. Thus, prophethood is an eloquent expression of God love for creation and His will of guiding them to the right way of belief and behaviour (Abdalati 1987). Therefore, the concept of revelation and prophethood and its significance in the human society underline God justice to humanity. For, He shows the guidance to him/her and then holds him/her responsible for his/her behaviour.

\section{Islamic Society as a Model Society}

Islamic conception of society, as mentioned earlier, is not based on race, nationality, locality, occupation, kingship, or special interest. It is tawhid (belief in the Oneness of God) manifested in man's submission to the Will of God, obedience to His law and commitment to His cause that constitute its basis. Therefore, Islamic society is the one fostered and nourished by Islam and has a historical mission which caste across physical boundaries, geographical location and goes beyond mere survival, sheer power, breeding or physical continuity. This is clearly stated in the Quran (3:104):

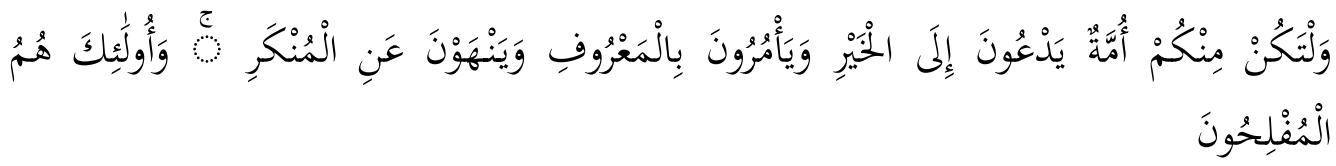

Let there be a community or ummah among you, advocating what is good, demanding what is right and eradicating what is wrong. They are indeed successful.

Thus, it is on the account of the historical role of demonstrating the virtuous, life both on individual and social levels that Islamic society can be considered as a modal society for the whole of humanity. Islam views society as an organic entity which patterns of social relation network are free from 'opposition, contention, and confrontation of the interest of different classes. It also integrates different elements into a single people or ummah through religious principles and institutions with the aim of creating a society, which, in its totality as well as within the heart of individual members, reflects tawhid and illustrates the functioning of the 
divine well in life of humankind (Nasr 1994). It attains unity in all domains of life and removes any destructive competition and confrontation as regard to various classes of human society based on sex or social status.

The strength of social relation in the Islamic conception of society is seen in the active role played by both individual and the society. The prophet (s.a.w.) describes the role of individual. Recorded by Imam Muslim (1954) in Kitab al-'Iman (Bab Bayan Kawn al-Nahy 'an alMunkar min al-'Iman wa 'ann al-'Iman Yazid wa Yanqus):

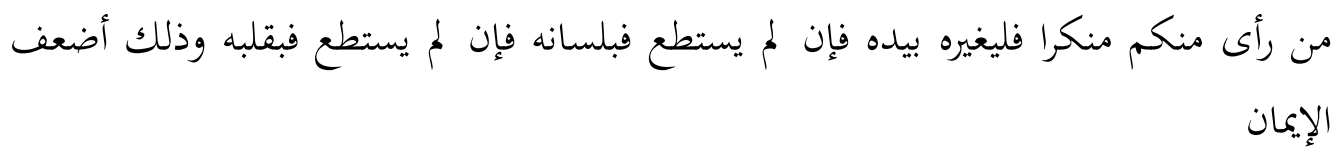

Whoever of you see something wrong must seek to rectify it by action or deed, if he cannot, let him to change it by words, if he cannot, let his feeling of disapproval and condemnation intensify and this is the minimal degree of faith.

From this statement of the prophet (s.a.w.) it becomes clear that in the Islamic conception of society, the individual is duty bound to play active role in elimination of the vice and promotion of good in society. In the same way, the society is responsible for promotion of good and the prevention of evil as a whole. It is due to this characteristic, as stated earlier, that it is praised in the al-Quran $(2: 143)$ as the middle nation.

The meaning of witnessing as a role of Islamic society in the context of this verse is that the community of Islam must be exemplary in setting the highest standard of performance both on societal and individual levels. By avoiding excess and extravagance, static rigidity, it must be able to present a middle course of action, hence providing a reference point for others. It must remain steadfast and consistent, know what is acceptable and what is rejectable, and have the principle of permanence and movement, the hardest test of human character and social viability (Abdalati 1987). It is in the light of above role and qualities that Islamic community is described as the best human community ever evolved. In Islamic conception of society individual, members are entrusted with the responsibility to do everything within their means for its safeguard and continuity. To this end, certain roles are set, for example, the rules of marriage, the rules of inheritance, the duties of zakat and hajj and the mutual rights and obligations of kin and the individual awareness of social belonging. All these are meant to secure the healthy continuity of the Muslim community.

\section{Human Nature}

Islam is not simply abstract ideal but a code of life, a living force that can manifest itself in every aspect of human life. It considers individual as the centre of gravity, which can put Islam or any other system into full action on a full scale. It is in recognition of this fact that Islam in its programme of reforms always begins with individual and prefers quality to quantity. Therefore, it is of relevance here to discuss some of the constituent elements of human nature, and how they are nurtured and how they affect human behaviours. According to Islam there are two aspects of human nature, internal and external which are intimately interrelated and continually interact with each other.

\section{The Internal Aspect}

The internal aspect of human nature consists of ruh (soul or self or heart) and 'aql (intellect or power of reasoning and intelligence) and is responsible for all spiritual, moral and intellectual activities. On the other hand, the rest of his activities come under the purview of external aspect 
of his nature. The interrelationship of both external and internal aspects of human nature is an obvious fact that cannot be denied. After all, it is universally accepted fact that man does not live by bread alone (Abdalati 1987). Accordingly, Islam devised proper measures for the nourishment of both internal and external aspects of human nature. In the case of former, it introduced certain measures to organize the spiritual or moral life of man in a manner that is conducive to all spiritual nourishment needed for piety and righteousness, for safety and peace. The measure provided by Islam for the purpose manifest themselves in the form of prescriptions of certain acts, which if fully applied, will bring about maximum positive result, hence leading to man spiritual growth, maturity and healthy social relation.

One of these prescribed acts is salat (prayer) which constitutes one of the five pillars of Islam and is performed five times a day. It has significant effect of cultivating sound personality in man, actualises his aspiration in a mature course of development, and restrains him from indecent and unjust deeds. This is stated in the al-Quran (29:45): "And establishes regular prayer, for it restrains one from indecent and unjust deeds". Failure to observe prayer without any valid reason is considered as a grave sin, for it is not against God only but also against his nature. This is because human has the natural tendency of adoring the great being, and the inspiration of lofty goal. The greatest and of the loftiest goal of all is God. The benefits of prayer are immeasurable and its blessing beyond imagination. It is not just a theory but a fascinating fact and spiritual experience, for it strengthen man's belief in God and enable him to realize his natural aspiration of greatness and high morality. It also purifies his heart, develop his mind, foster the good and decent elements in him, and suppress the evil and indecent inclination (Abdalati 1987). Therefore, Islamic prayer is not merely physical motion but is a formula that combines intellectual mediation, spiritual devotion, moral elevation, and physical exercise all at once.

Sawm (fasting) is another prescribed act, which is designed for the development of spiritual and moral aspect of human nature. It resemble to an ever-growing tree of infinite virtue and invaluable products. Because through it, man learns the principle of sincere love and equip himself with a creative sense of hope and an optimistic outlook on life. Besides this, it inculcates in him a genuine virtue of devotion and dedication to God, for he fasts for His sake only without any external pressure. Furthermore, fasting cultivates a vigilant and sound conscience and indoctrinates in him a sense of patience and unselfishness. It is because as he fast, he feels the pain of deprivation and endures it, and as a result of this experience, he realizes the severe effect of such pains on others who are deprived of the essential commodities and needs. Thus, fasting is an eloquent expression of unselfishness and genuine sympathy and taqwa, self-restraint. As stated in the Quran (2:183):

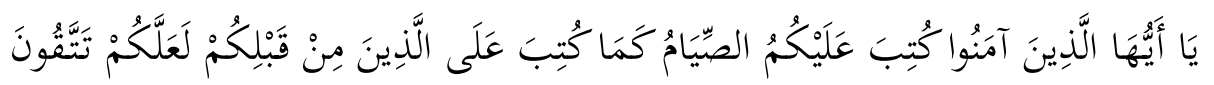

Oh who believe! Fasting is prescribed for you as it was prescribed for those before you, that you may learn taqwa.

Taqwa in its literal sense means fear of God but in general sense; it connotes an expression of piety based on the fear of God, the fountainhead of the wisdom. However, it is important to note that Fear of God is out of love and reverence for Him, therefore, height of morality and goodness, which come from within the soul itself and express itself in complete obedience to the law of God, the source of real welfare of humankind (Muhammad 1977). In sum, fasting has spiritual as well as material benefits. From spiritual aspect it foster in man a sense of sympathy and help for God's creature, which pleases God the most. From physical aspect it incurs material benefits that are conducive to physical health and firmness with which he can cope with adversity in life. 
Zakat (tax or almsgiving) is another prescribed act, which nourishes spiritual and moral aspects of human nature. It is a form of charity and almsgiving and an expression of kindness. Like prayer, it is one of the five pillars of Islam and is enjoined by God on Muslims with means, in the interest of the society as a whole. In the context of the al-Quran, it is used in a much broader sense than mere charity. It includes charity, almsgiving, official tax, voluntary contribution, combined with kindness God-mindedness and spiritual as well as moral motives. In its literal sense, it means purification, for it purify one's heart from misery and greediness, and discipline him. The undertaking of this duty by individuals in the society has multifaceted effects. From individual aspect, it contributes to self-discipline, by eliminating the quality of miserliness on the part of giver, and the quality of envy and ill feeling on the part of recipient. And from the societal aspect it leads to the eradication of poverty and a strong sense of social responsibility (Abdalati 1987). Thus, a society in which the relations of individual members is dominated by a sense of sympathy unselfishness is poised to get rid of all evil tendencies such as class warfare, suspicion, ill feeling and distrust, corruption and disintegration.

Accordingly, zakat should not be treated merely as one of the five pillars of Islam, but must be examined in the context of its social and economic effect on the society as a whole, which is the abolition of poverty. In this sense zakat is the most effective way of eradication of social misery, for the soundness of social structure highly depend on the sound economic basis (Muhammad 1977). This is because through zakat the gap between rich and poor in the society is narrowed, as the wealth in society is not exclusively accumulated by few each benefit from it. However, it is important to note that not everyone in the society is eligible for receiving zakat. There are certain categories of people who are entitled to it. Its beneficiaries are mentioned in the following Quranic verse (9:60).

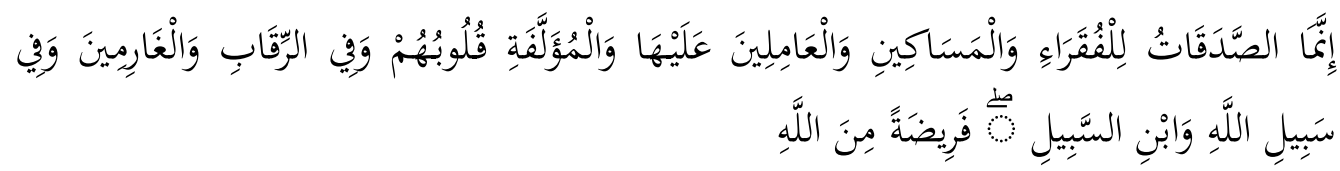

The alms are only for poor and needy, and those who collect them and those whose hearts are to be reconciled and to free the captive and the debtors, and for the cause of God, for the wayfarer, a duty imposed by God.

Consequently, the spiritual significance of zakat is much deeper and lively. This is because, when a person with means pay zakat it purifies the property from the share which is due to others. But if he does not pay it to the rightful person, it is tantamount to retaining something, which does not belong to him. This is considered corruption and plain usurpation from moral, spiritual, legal and commercial point of views. On the other hand, when zakat is paid to the rightful beneficiary the remaining portion of property acquire purity and decency, the requisites of permanent prosperity and honest transaction. Zakat also mitigate the suffering of the poor section of the society to a minimum level and provide the most comforting consolation to the less fortunate people. Needy conceive it as an emergency measure, which he does not depend on completely but strive hard to fend for himself as well as for others. To contributor, it is a warm invitation for more earning and benefits. Hence, to both parties; recipient and contributor, zakat present an open treasure for spiritual investment.

Zakat besides being the most effective way of the eradication of social misery, is a healthy form of internal security for human nature against selfish greed and social dissension, and against the intrusion of subversive ideologies. It is because, through it the sense of social responsibility on part of contributor, and the feeling of security and belonging on the part of recipient is cultivated. It is also a living manifestation of spiritual and humanitarian spirit of responsive interaction between the individual and the society. For, it illustrates the fact that though Islam value private possession, yet it does not tolerate selfish and greedy capitalism. 
Therefore, zakat express a general philosophy of Islam that adopt a moderate and middle course between the individual and the society, between the citizen and the state, between capitalism and socialism and between materialism and spirituality (Abdalati 1987).Thus, zakat functions as a guard against selfish greed, social dissension and the influence of alien ideologies.

Hajj (pilgrimage) to Mecca is another prescribed institution of Islam that caters for the nourishment of the soul on global scale. It is obligatory, at least once in lifetime, upon every Muslim male or female, who is mentally, physically, and financially fit. Hajj literally means 'setting out', 'tending towards' while, technically it stands for pilgrimage to Mecca in the month of Zul-Hijjah (Muhammad 1977). It is the fifth pillar of Islam incumbent on Muslims with means which prescription is expressed in the Quran (2:197) as follow:

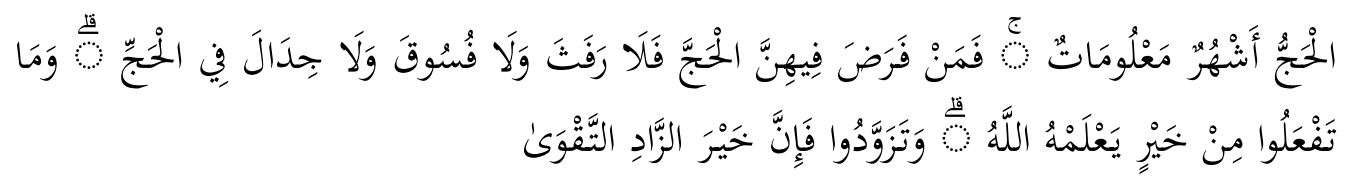

For hajj are the months well known if any one undertakes that duty therein, let there be no obscenity, nor wickedness, nor wrangling in the hajj. And whatever good you do in the hajj, God knows it and take a provision with you, but the best provision is taqwa or right conduct.

Taqwa in the above verse, as has been pointed out by commentators, means righteousness, and right conduct as well. Because, hajj is an occasion where a large number of Muslims meets, it therefore, presents a trial and test of the conduct of the believers towards others. Sincerity and discipline in the performance of the rites is strictly demanded. No indecency and wrangling are permitted at this occasion (Abdalati 1987). Thus, it is a course of spiritual enrichment and moral rearmament and a course of intensified devotion to God, for, all the material interests are forsaken in His service. Besides spiritual and moral enrichment and intensified devotion to God, which individual Muslim gains through performing hajj, it also has some social benefits. For, it provides an opportunity for the believers to meet and discuss their social welfare and work out solutions for their problem at the global level. It also gives a lesson of the equality of social status among the believers, as is conspicuous from the likeness of the garments prescribed for pilgrims (Muhammad 1977). While, zakat furnishes an individual with the sense of self-discipline and provide for social security, hajj teaches him the etiquette of social life and social behaviour.

The institution of hajj, like other fundamental institutions, which are represented by five pillars of Islam, serves many purposes. It serves as the annual convention of Faith dominated by sphere of peace with God, and one's soul, peace with one another and animal, through which Muslims know each other, and promote their welfare. It also demonstrates the universality of Islam and the brotherhood and equality of all Muslims. For, they come from different parts of the globe from different walks of life in response to the call of God, wearing the same garment, performing the same rites and observing the same regulation. Furthermore, it strengthen Muslims commitment to God by forsaking material interest in His service, and acquaints the pilgrims with the spiritual environment of the prophet Muhammad (s.a.w.) from which they derive warm inspiration that strengthens their faith. It also serves as the commemoration of the divine ritual performed by Abraham and Ismael, the first pilgrims to the first house of God on Earth, and as a reminder of grand assembly on the Day of Judgement, where no superiority of race or stock can be claimed (Abdalati 1987). From the forgoing discussion, it becomes clear that Islam is not merely a belief but also an expression of righteous acts, the total sum of which constitute its social life and facilitate social solidarity. The pillars of Islam are structured in a manner that they first aim, at the soul the internal aspect of human nature, which is the abode of emotions and desires and nourish him with the qualities that keep his desire under control. 
Desire, as Muhammad Muslehuddin (1977) has pointed out is often so personal that its satisfaction lead man to deviate from the right path. Thus, its control is more significant than its satisfaction and it is well said that it is better to be a human being dissatisfied than a pig satisfied'.

\section{The External Aspect}

The external aspect of human nature is not less complex than its internal aspect. It can be divided to division and subdivision. However, it is important to note that the soundness of the former is heavily dependent on the latter. Therefore, Islam extended divine touch to both aspects of human nature in order to maintain balance between them without which it can be destructive and fatal. Islam nourishes external nature of man from personal aspect in terms of purity, cleanliness, healthy diet, and proper manner of clothing and behaviour. To this effect, it emphasis on keeping the body, clothing, houses, and streets clean. Of particular importance is its stress on the cleanliness of teeth, hands, and hair (al-Qaradawi 1985). This emphasis on cleanliness is not to be wondered at in Islam, for it makes cleanliness the key to its principle form of worship, salat, which acceptance requires cleanliness of body, clothing, and the place on which it is performed. Therefore, cleanliness is daily concern of Muslim, for he has to pray five times every day, maintaining ritual purity, preserving the body and clothing from contamination by excretions and blood. Muslim has to offer prayer everyday with pure heart and mind, in clean body and cloth, on pure ground and intention.

Therefore, to maintain pure heart and sound mind, and to nourish an aspiring soul, a clean and healthy body, Islam pays special attention to diet. It allows all the things that are pure themselves and good for man and forbids all impure, bad, and harmful things under ordinary circumstances. The pure and lawful diet is mentioned in the Quran (5:4) $(2: 173)$ as follow:

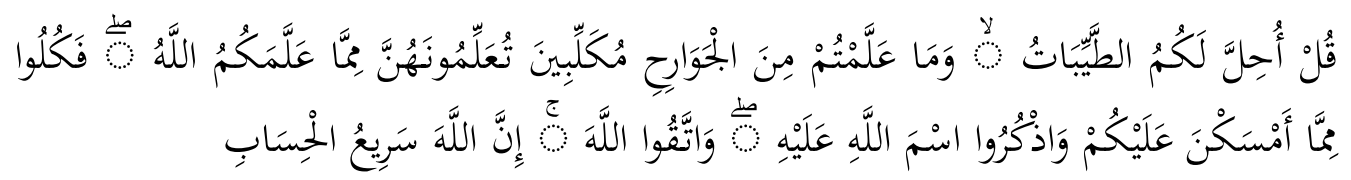

Say, lawful onto you are (all) things good and pure, and what ye have taught, your trained hunting animals (to catch) in manner directed to you by God: Eat what they catch for you. But pronounce the name of God over it; and fear God, for He is swift in taking account.

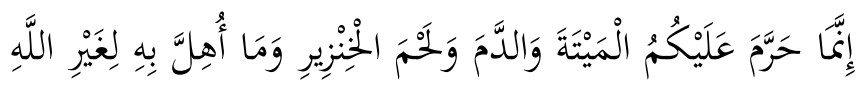

He hath only forbidden you dead meat, and blood, and the flesh of swine and that on which any other name hath been invoked beside that of Allah.

The reasons for the prohibition of the above dietary elements is that their consumption damage human decency, and cause harm to his health, and diminishes his sense of shame in relation to what is indecent. In addition to specifying the impure and unlawful food, as harmful and destructive to human spirit and morality as well as his physique, Islam also forbids consumption, sale and possession of all intoxicating drinks. However, exemption is made in the case of necessity with regard to its use. The reason for prohibition of substance that has intoxicating effect on man is that it befogs or clouds the mind; impair its faculties of thought, perception, and discernment. Once a person shows such symptoms because of consumption of intoxicating substance, his faculty of reasoning becomes weak and cannot make a proper 
decision. This leads to loose of control over himself hence, indulges in abusive behaviours that harm his social relation and status.

The prohibition of these dietary items, be it food or drinks, should not be seen in negative way, as an arbitrary action or a dictatorial decree of God. Rather it is divine interventions in the best interest of man for; it strengthens man's sense of good morality and wisdom and contributes to his health and wealth, piety and common behaviour. In sum, the reasons for divine intervention can be classified as intellectual and spiritual, moral and mental, physical and economic. And the only purpose is to teach man how to develop himself in according to the divine guidance, so as to become a healthy unit in the structure of the family, than of society and finally of humanity as a whole.

Clothing and adornment constitute another important element of the measures taken by Islam for the nourishment of the external nature of man from personal aspect. In this regard, Islam requires man to abide strictly by the principles of decency, modesty, chastity, and manliness. Any clothing material or element of adornment, which is not compatible with attainment, or maintenance of such quality is prohibited in Islam (Abdalati 1987). Also, the garment and the dressing manner, which are conducive to arrogance or pride, are prohibited. Islam prohibits two types of adornment, gold ornaments and clothing made of pure silk for man while, permitting them for women. The reason is that it weakens his morality and undermine him manliness (al-Qaradawi 1985).

Accordingly, man should remain loyal to his manly nature, which God has chosen for him. He should avoid all the things, which weaken his character. For this reason, Islam warns men against wearing cloth made out of pure silk, and against the use of certain precious stones, e.g. gold, because these things suit the feminine nature. Therefore, the handsomeness of man is not in wearing precious stones or purely silken cloth, but in high morality, sweet nature, and sound conduct (Abdalati 1987). Besides, preserving the manliness of man the underlying purpose of this prohibition is to combat luxuriousness, which from point of view of Islam is the cause of weakness among the nations and their eventual downfall. This is because the existence of luxury is the expression of social injustice, as only a few can afford luxurious items at the cost of deprived masses of people (al-Qaradawi 1985). From the preceding discussion it is clear that the manner of clothing and ornament has practical consequence on the behaviour of man. Islam safeguards the natural instinct of both man and woman by confining them to their respective manner of dressing and ornament thus, endowing them with modesty and high morality.

Sports and amusement constitute other elements of the measure taken by Islam for the development of external nature of man. In fact most of the Islamic forms of worship, even though are basically meant for spiritual purpose, show some sportive characteristics. This implies that there is a constant interaction between man's moral and physical aspects or in other words, this underscores the fact of the interrelatedness of the external and internal aspects of the human nature. Islam therefore, encourages any physical or mental activities that lead to sound thinking or refresh mind and revitalize body and keep man in healthy shape. Provided that it does not anticipate or involve sin, or cause harm and delay in the fulfilment of other obligations (Abdalati 1987). The prophet (s.a.w.) has said that all believers in God have good qualities but the strong one is better than the weak. In Islamic perception, life has a definite purpose and no one is allowed to abuse it by letting it be dependent entirely on luck and chance. Because of the loftiness of the purpose of the life Islam extends its divine touch to the very personal aspects of man to organize it in a way that is conducive to attainment of the noble purposes. Among the measures taken in this respect is prohibition of gambling which is tension accelerating than tension reducing. Therefore, subjecting life to luck and mere chance is considered as deviation from the normal course of life. It causes unnecessary mental strains and shattering of nerves. Islam by forbidding gambling of all forms and kind protected man from such problem. 
As a conclusion, Islam conceives society as association of the individuals formed in according with divine law with the purpose of achieving a harmonious and peaceful coexistence. Its conception of society is comprehensive and dynamic, for it does not compartmentalize the material and spiritual aspects of life but treat them as an organic whole. The divine law constitutes the base of society in Islamic conception. It considers every individual as a social unit, for, it is through his qualities and actions that social relation emerges. Therefore, individual personality is developed through the cardinal principles that have multidimensional effects, contributing to the welfare of the society. Believe in the Oneness of God as the fundamental principle plays a crucial role in the social relation network, for, it endows individuals with a sense of accountability to God and responsibility towards society. Thus, Islamic conception of society presents a realistic view of society by taking care of the individual and directing him/her in a direction that is conducive to good behaviour hence, good social relations.

On the contrary, sociology trivializes individuals and speaks of society in a theoretical manner, which is fruitless. Unity and brotherhood is the basic principle of Islamic social order. It advocates the unity of human being and their equality before God for, they are all descendants of Adam and Eve. This realization purifies human beings' mind from social prejudice or social injustice and lead to the unity of social behaviour among individuals. However, this unity is not conceived only in terms of origin of human being but also in terms of their ultimate goal, hence, providing a firm theoretical foundation for the relationship between individual and the society. Cooperation in goodness and piety is another important element of an Islamic social system for, every individual is required to play an active role in the domain of social moral and ethics by promoting good and preventing evil.

Islamic society is a model society for it sets the highest standard of behaviour by taking a balanced approach in its framework of social relations. It has the historical mission of demonstrating a virtuous life both on individual and societal level. In its totality it reflects the functioning of the divine Will in lives of human beings. It attains unity in all domain of life by removal of destructive competition from the sphere of its social relations network. Both the individual and society play active roles in the realm of moral and ethical commitment. Islam considers the Individual as the centre of gravity in the whole scheme of social relations. Therefore, it nurtures and nourishes both internal and external aspects of his nature by devising certain measures. The Internal aspect of human being which consists of the soul and the intellect and which is responsible for all moral and intellectual activities, is nourished by undertaking of the five cardinal principles which has multidimensional effect on the soul and the intellect. They are structured in a manner that primarily aims at the soul, which is the abode of motion and desire and nourishes it with the qualities that keep human desire under control. On the other hand, the external aspect of human nature is nurtured from personal aspect, in terms of purity, cleanliness, healthy diet, and proper manner of clothing and behaviour. Islam pays attention to diet in order to maintain a pure heart and sound mind and to nourish an inspiring soul and a clean and healthy body. Therefore, it allows all pure and good things and forbids all impure, bad and harmful things under ordinary circumstances. These are meant to strengthen human being sense of morality and wisdom and to contribute to their health and wealth, piety and common good behaviour. 


\section{References}

Al-Quran.

Abdalati, Hammudah. 1978. Islam in Focus. Kuwait: The International Islamic Federation of Student.

Abu Sulayman, `Abdul Hamid (ed.). 1989. Islamization of Knowledge: General Principles and Work Plan. Virginia: International Institute of Islamic Thought.

Al-Buti, Muhammad Sa'id Ramadan. 1987. Islamic Law: Its Scope and Equity. Kula Lumpur: Muslim Youth Movement of Malaysia.

Muslim, Abu al-Husayn ibn al-Hajjaj. 1954. Sahih Muslim. Juz. 1. Tahqiq. Muhammad Fu'ad `Abd al-Baqy. Beirut: Dar 'Ihya' al-Turath al-'Arabiy.

Hitti, P.K. 1961. The Near East in History. New York: D. Van Nostrand Company Inc.

Kerr, M.H. 1966. Islamic Reform. California: Princeton University.

el-Mesawi, Mohamed Tahir. 1998. A Muslim Theory of Human Society. Selangor: Thinkers Library Sdn. Bhd.

Muhammad Muslehuddin. 1977. Islam and Sociology. Lahore: Islamic Publication Limited.

Nasr, Seyyed Hossein. 1994. A Young Muslim's Guide to the Modern World. Petaling Jaya: Mekar Publisher.

al-Qaradawi, Yusuf. 1985. The Lawful and Unlawful in Islam. Transl. Kamal El-Helbawi et al. United Kingdom: Shrouk International.

al-Shatibi, Abu Ishaq Ibrahim. 1087AH. Al-Muwafaqat fi Usul al-Shari ah. Cairo: al-Maktabah alTijariyyah. 